\title{
Sources of medical information of patients referred to colorectal surgery outpatient clinic for hemorrhoidal disease
}

\author{
Piotr Spychalski ${ }^{1} \odot$, Adrian Perdyan² $\odot$, Dariusz kaski ${ }^{1} \oplus$, Jarek

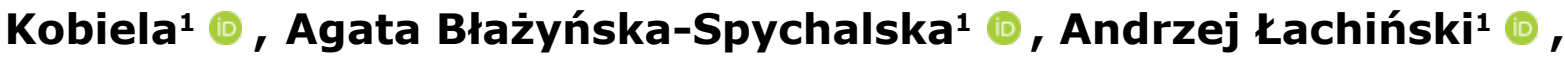 \\ Zbigniew Śledziński ${ }^{1}$
}

${ }^{1}$ Department of General, Endocrine and Transplant Surgery, Medical University Gdańsk, Poland

${ }^{2}$ Students' Scientific Circle at Department of General, Endocrine and Transplant Surgery, Medical University of Gdańsk, Poland

\begin{abstract}
Background: We surveyed patients with hemorrhoids about their behavior regarding searching for information about that disease and confronted it with data obtained from Google Trends website and Google searches. We aimed to determine sources of information on hemorrhoids used by patients. Secondary aim was to assess the quality of information provided by Internet in particular. Materials and methods: We collected 78 surveys from patients of the outpatient surgical clinic at Medical University of Gdańsk, in which we asked about sources of information about hemorrhoids. We used Google Trends to analyze most often used search queries associated with that topic. In result, we analyzed the content of top 10 Google search results of that queries in order to verify reliability. Results: Over $80 \%$ of surveyed patients looked for information about that disease online, $50 \%$ of whom were satisfied with the quality of information obtained. Our Google Trends analysis showed that term hemorrhoids has overwhelming prevalence in comparison to remaining terms. Analysis of top 10 Google search results showed that 7 in 10 organic links lead to websites with professional information about hemorrhoids. Conclusions: Patients use the Internet as a source of knowledge about hemorrhoids and find it satisfactory. Moreover, our research indicates that this information is reliable.

Keywords: hemorrhoids $•$ Internet/Patient Preference - Google Trends • search engine
\end{abstract}

\section{Citation}

Spychalski P, Perdyan A, Łaski D, Kobiela J, Błażyńska-Spychalska A, Łachiński A, et al. Sources of medical information of patients referred to colorectal surgery outpatient clinic for hemorrhoidal disease. Eur J TransI Clin Med. 2019;2(1):36-43.

DOI: $10.31373 / \mathrm{ejtcm} / 105778$

Corresponding author:

Adrian Perdyan, Students' Scientific Circle at Department of General, Endocrine and Transplant Surgery, Medical University of Gdańsk, Poland

e-mail: 532at@gumed.edu.pl

No external funds.

Available online: www.ejtcm.gumed.edu.pl

Copyright ${ }^{\circledR}$ Medical University of Gdańsk

This is Open Access article distributed under the terms of the Creative Commons Attribution-ShareAlike 4.0 International. 


\section{Introduction}

Nowadays, patients' self-consciousness is rising with World Wide Web as one of the most important sources of medical knowledge [1]. It is caused both by the growing amount of medical content in the Internet and by the growing percentage of population with Internet access [2-3]. Besides medical literature, newspapers and pamphlets, patients often choose the Internet which seems to be more accessible source of information about bothersome symptoms than a visit in physician's office. While self-diagnosing techniques (e.g. self palpation of the perianal area or self examination per rectum) which are explained on the Internet may seem sufficient in some cases, hemorrhoids should be diagnosed by a medical practitioner. Hemorrhoidal disease should be diagnosed after detailed history-taking and an accurate physical examination, including per rectum examination [4]. Moreover, internal hemorrhoids, which do not prolapse, can only by diagnosed by physician [5].

In this study we aim to determine sources of information on hemorrhoids used by patients. Secondary aim of the study is to assess the quality of information provided by Internet in particular.

\section{Materials and methods}

\section{Study concept}

We hypothesized that patients often search for information about hemorrhoidal disease independently and that Internet may be an important source of this information. Therefore, we designed this study in three-stage manner. As a first step we collected from patients surveys on hemorrhoidal disease. As a second step, based on the information gathered from surveys, we conducted a Google Trends analysis. In the final step we analyzed information on the patients' search behavior and assessed the quality of information they found in the Internet.

\section{Survey}

We collected 78 surveys from 78 patients of the outpatient surgical clinic at the Medical University of Gdańsk. The survey was anonymous and voluntary. Only the patients referred from general practitioner with either a suspicion or diagnosis of hemorrhoids were asked to complete the survey. Survey established following information: respondents' demographics, availability of an Internet connection, cause of the visit, presence or suspicion of hemorrhoids, source of knowledge about symptoms and treatment, reliability of that information and information about self-medication. Statistical calculations were made with Statistica 12 software (2014, Stat Soft, Inc., Tulsa, USA).

\section{Google Trends}

On 14.09.2018 we queried Google Trends and downloaded the data for the following search input ["hemorrhoids"+"anal varices"+"anal bleeding"] [original polish queries: "hemoroidy"+"żylaki odbytu" +"krawawienie z odbytu"] Based on methodology suggested by Nuti et al [6]. Although hemorrhoids and anal varices are synonymous but rather two different diagnoses, we chose to include them in the search query as in common language they are often used interchangeably by mistake [7]. We searched within Poland from January 1st 2006 to September 1st 2018. All query categories were used. We narrowed regional interest to Poland, because of language specificity of the query.

Upon initial Google Trends search we narrowed the queried terms to "hemorrhoids" because it was the most often used term according to Google Trends in comparison to remaining terms ( 79 vs 6 vs 6 respectively).

Results in Google Trends are shown in a relative manner. Numerical data values represent search interest relative to the highest point on the chart for the given region and time. A value of 100 is the peak popularity for the term. Popularity is measured in comparison to all of Google searches in specified time and location. A value of 50 means that the term is half as popular. Likewise, a score of 0 means the term was $<1 \%$ as popular as the peak results [8].

\section{Internet reliability}

Based on the previously determined search term we conducted a Google search and analyzed results from the first page and screened professional or non-professional websites. Each link was categorized into: organic (if it was an organic Google search result) or advertisement (if it was part of the Google Ad Words campaign); professional (if it was authored by a Medical Doctor (MD) or based on medical literature) or non-professional (drug company website, health-promoting website, outpatient clinic website or an open encyclopedia).

The first page of search results represents over $90 \%$ of the traffic and thus second and further pages weren't included into the study [9]. We chose not to assess data from either MSN or Yahoo! due to Google's overwhelming market-share in Poland [10]. On 21.08.2018 and 28.08.2018 two researchers with medical background performed 2 separate series of searches for the term "hemorrhoids" using Google 
Chrome, Firefox, Opera, Google Chrome Mobile, Safari Mobile web browsers. All searches were done in "incognito mode" to exclude any interference from cached files. Four most popular Google Ad Words results were chosen to be included into the study.

\section{Survey}

Abbreviated results are presented in Table 1 . Full results are available in Appendix 1. Median age of participants was 47 years. Definite majority of respondents were female, university-educated and living in urban areas. Almost 9 out of 10 patients had Internet access. Most common causes for referral to the colorectal surgery outpatient clinic were: suspicion of hemorrhoids (53.8\%) and diagnosed hemorrhoids (28.2\%). Most patients (73.1\%) diagnosed themselves, while physician diagnosing remaining $26.9 \%$ was either GP or a specialist. Less than 1 in 4 patients were ever examined per rectum.

Table 1. Abbreviated results of the survey

\begin{tabular}{|c|c|c|}
\hline \multicolumn{3}{|c|}{$\begin{array}{l}\text { Did you look for information } \\
\text { about hemorrhoids? }\end{array}$} \\
\hline & $\mathrm{n}=78$ & $\%$ \\
\hline Yes & 63 & $80.8 \%$ \\
\hline No & 13 & $16.6 \%$ \\
\hline Not answered & 2 & $2.6 \%$ \\
\hline \multicolumn{3}{|c|}{ Were you satisfied } \\
\hline & $\mathrm{n}=78$ & $\%$ \\
\hline Yes & 40 & $51.3 \%$ \\
\hline No & 30 & $38.4 \%$ \\
\hline Not answered & 8 & $10.3 \%$ \\
\hline
\end{tabular}

Majority of patients (80.8\%) undertook Internet search regarding hemorrhoidal disease and half of them were satisfied with the results. Among most common sources of knowledge on the diseases and their treatment (\% respectively) were: physicians (44.9\%; 53.8\%) and the Internet (44.9\%; 32.1\%). Over half of the respondents self-medicated, most often with suppositories (46.2\%) and creams or ointments (44.9\%). Almost $1 / 3$ changed their diet. In over 7 of 10 of cases those efforts were at least partially successful.

Personal computer was the most common device used to access the Internet $(74.4 \%)$ while mobile devices placed second (27\%). Scientific associations' WebPages, scientific journals' WebPages and National Health Fund (NFZ) webpage were generally found to be trustworthy while Internet forums, popular media, pharmaceutical companies' WebPages and WebPages for patients were not. Only 1 in 5 respondents chose to attach suggestions regarding improvement of the available information. The most frequently mentioned ideas were: the physician should collect a more detailed patient history (25\%), pamphlets in outpatient clinics (19\%), creating a dedicated medical web service (19\%) and easier access to specialists (41\%).

\begin{tabular}{|c|c|c|}
\hline \multicolumn{3}{|c|}{$\begin{array}{l}\text { What was your source of information } \\
\text { about symptoms of hemorrhoid disease? } \\
\text { (multiple choice question) }\end{array}$} \\
\hline & $\mathrm{n}=78$ & $\%$ \\
\hline Physician & 35 & $44.9 \%$ \\
\hline Newspapers & 30 & $38.5 \%$ \\
\hline Pamphlets & 25 & $32.1 \%$ \\
\hline Internet & 35 & $44.9 \%$ \\
\hline \multicolumn{3}{|c|}{$\begin{array}{l}\text { How many sources of information } \\
\text { about symptoms did you use? }\end{array}$} \\
\hline & $\mathrm{n}=78$ & $\%$ \\
\hline One & 23 & $29.5 \%$ \\
\hline More than one & 55 & $70.5 \%$ \\
\hline
\end{tabular}




\begin{tabular}{|c|c|c|}
\hline \multicolumn{3}{|c|}{ Was this information helpful? } \\
\hline & $\mathrm{n}=78$ & $\%$ \\
\hline Yes & 67 & $85.9 \%$ \\
\hline No & 6 & $7.7 \%$ \\
\hline Not answered & 5 & $6.4 \%$ \\
\hline
\end{tabular}

Have you tried self-treatment?

\begin{tabular}{|l|c|c|}
\hline \multicolumn{1}{|c|}{} & $\mathrm{n}=78$ & $\%$ \\
\hline Yes & 42 & $53.9 \%$ \\
\hline No & 27 & $34.6 \%$ \\
\hline Not answered & 9 & $11.5 \%$ \\
\hline
\end{tabular}

Was the treatment successful?

\begin{tabular}{|l|c|c|}
\hline & $n=78$ & $\%$ \\
\hline Yes & 22 & $28.2 \%$ \\
\hline Partially & 34 & $43.6 \%$ \\
\hline No & 9 & $11.5 \%$ \\
\hline Not answered & 13 & $16.7 \%$ \\
\hline
\end{tabular}

What type of treatment have you used? (multiple choice question)

\begin{tabular}{|l|c|c|}
\hline & $\mathrm{n}=78$ & $\%$ \\
\hline Diet & 25 & $32.1 \%$ \\
\hline Hygiene & 16 & $20.5 \%$ \\
\hline $\begin{array}{l}\text { Ointments } \\
\text { and creams }\end{array}$ & 35 & $44.9 \%$ \\
\hline Suppositories & 36 & $46.2 \%$ \\
\hline Tablets & 10 & $12.8 \%$ \\
\hline
\end{tabular}

How many types of treatment did you use?

\begin{tabular}{|l|c|c|}
\hline \multirow{2}{*}{ One } & $\mathrm{n}=78$ & $\%$ \\
\hline More than one & 35 & $38.5 \%$ \\
\hline Not answered & 13 & $44.9 \%$ \\
\hline
\end{tabular}

Appendix for table 1. Abbreviated results of the survey

\begin{tabular}{|c|c|c|}
\hline \multicolumn{3}{|c|}{ Do you have access to the Internet? } \\
\hline & $\mathrm{n}=78$ & $\%$ \\
\hline $\begin{array}{l}\text { At home, } \\
\text { tablet, } \\
\text { smartphone }\end{array}$ & 68 & $87.1 \%$ \\
\hline $\begin{array}{l}\text { At friend's } \\
\text { or family's } \\
\text { home }\end{array}$ & 0 & $0.0 \%$ \\
\hline Other & 2 & $2.6 \%$ \\
\hline No & 7 & $9.0 \%$ \\
\hline Not answered & 1 & $1.3 \%$ \\
\hline
\end{tabular}

What is the cause for your visit?

\begin{tabular}{|c|c|c|}
\hline & $\mathrm{n}=78$ & $\%$ \\
\hline $\begin{array}{l}\text { Suspicion of } \\
\text { hemorrhoids }\end{array}$ & 42 & $53.8 \%$ \\
\hline $\begin{array}{l}\text { Confirmed } \\
\text { hemorrhoids }\end{array}$ & 22 & $28.2 \%$ \\
\hline Else & 10 & $12.8 \%$ \\
\hline Not answered & 4 & $5.2 \%$ \\
\hline
\end{tabular}

Did your GP performed

a per rectum examination?

\begin{tabular}{|c|c|c|c|}
\multicolumn{2}{|c|}{} & $n=78$ & $\%$ \\
\hline Yes & $\begin{array}{r}26.3 \% \\
(n=19)\end{array}$ & 5 & $6.4 \%$ \\
\hline No & $\begin{array}{r}73.7 \% \\
(n=19)\end{array}$ & 14 & $18 \%$ \\
\hline \multicolumn{2}{|c|}{ Not answered } & 59 & $75.6 \%$ \\
\hline
\end{tabular}

Did you look for information about hemorrhoids?

\begin{tabular}{|l|c|c|}
\hline \multirow{2}{*}{ Yes } & $\mathrm{n}=78$ & $\%$ \\
\hline No & 63 & $80.8 \%$ \\
\hline Not answered & 2 & $16.6 \%$ \\
\hline
\end{tabular}


Appendix for table 1. Abbreviated results of the survey

\begin{tabular}{|c|c|c|}
\hline \multicolumn{3}{|c|}{$\begin{array}{l}\text { What kind of device did you use to access } \\
\text { information about symptoms of hemorrhoid } \\
\text { disease? (multiple choice question) }\end{array}$} \\
\hline & $\mathrm{n}=78$ & $\%$ \\
\hline $\begin{array}{l}\text { Personal } \\
\text { computer }\end{array}$ & 58 & $74.4 \%$ \\
\hline Tablet & 8 & $10.3 \%$ \\
\hline Smartphone & 13 & $16.7 \%$ \\
\hline TV & 9 & $11.5 \%$ \\
\hline
\end{tabular}

\section{Google trends}

Changes in the amount of search queries over last 12 years were observed with median at 82 and minimal interest at 54 (maximal at 100 - as a result of calculation method). However there is a visible yearly pattern with lowest interest before and after holidays and during Christmas (respectively in May, June, September, October and December (75.2; 75.8; 72.6; 73.3; 75.3)) and highest during holidays and after Christmas (respectively January, February, July and August (83.2; 82.7; 83,4; 82.4)). (Graph 1, Panel B)

Variation in the amount of search queries across geographical location was observed with the lowest interest in Lodzkie and Zachodniopomorskie (87) voivodships and highest in Opolskie, Podlaskie, Swietokrzyskie and Lubuskie voivodships (100).

\section{Internet reliability}

First page of Google results for search term "hemorrhoids" was analyzed. Each contained 10 organic links and varying amount (from 1 to 4 ) of Ad Words

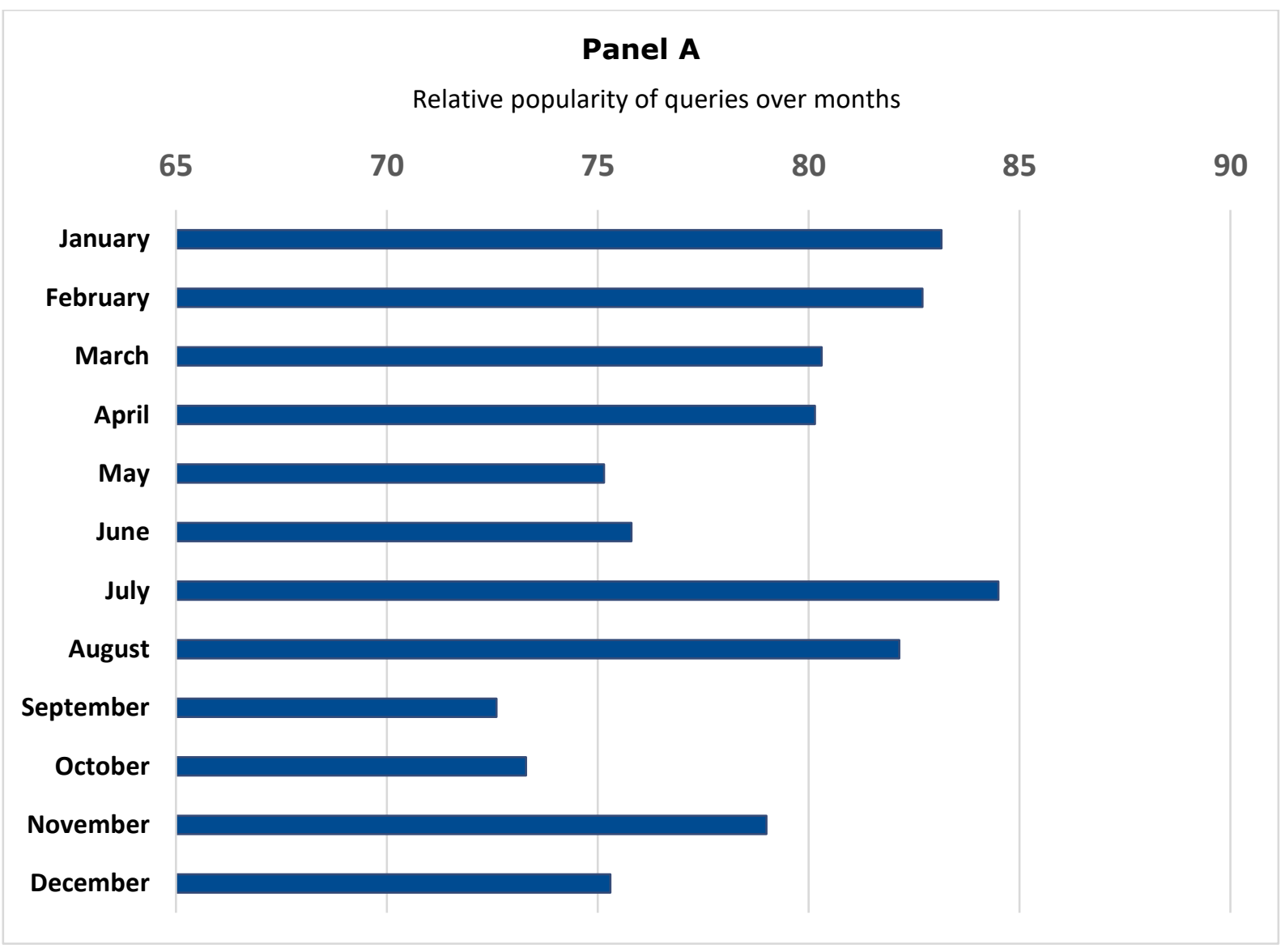


advertisement links [11]. Ad Words is a Google Inc. advertisement campaign tool which allows vendors to advertise their products and services in text-based search ads. Content of the displayed ads depends on searched terms, cached files and other factors [12]. Below we present results from analysis of links provided by the first page of Google search results. One hundred and twenty-one links were analyzed of which 21 were advertisements and 100 were organic. Only those ads that were displayed in at least 2 separate searches were included.

Total of 21 Ad Words ads linked to 4 websites of which 3 were non-professional and provided by drug companies, whereas 1 was categorized as professional (provided by a private practice outpatient clinic and authored by a MD).

Every analyzed Google search page contained the same 10 organic links of which 3 were non-professional and 7 were professional. Two out of three of the non-professional websites were provided by drug companies and presented modes of treatment and remaining one was a health-promoting website however it lacked literature sources or authorship information. Of the 7 websites classified as professional, 1 was an encyclopedia (therefore based on medical literature) and the remaining 6 were health-promotion websites ( 1 based on literature, the rest were authored by MD). Results with links to analyzed websites are in Table 2.

\section{Discussion}

Over $80 \%$ of the patients referred to our surgical outpatient clinic previously looked for information about hemorrhoids, thus showing a great demand for knowledge among them. Moreover, $73 \%$ of patients stated that they performed a self-diagnosis of hemorrhoids. In our group, Internet was used as often as professional advice to research the topic of hemorrhoids and overall percentage of patients that used Internet was $45 \%$ and similar to the findings of Diaz et al [13]. In contrast, over $87 \%(1016 / 1162)$ of the patients analyzed by Wong et al used the Internet to find health information. The most common sought topic was symptom $81.59 \%(829 / 1016)$ and the most common reason for choosing Internet was convenience $55.41 \%(563 / 1016)[14]$.

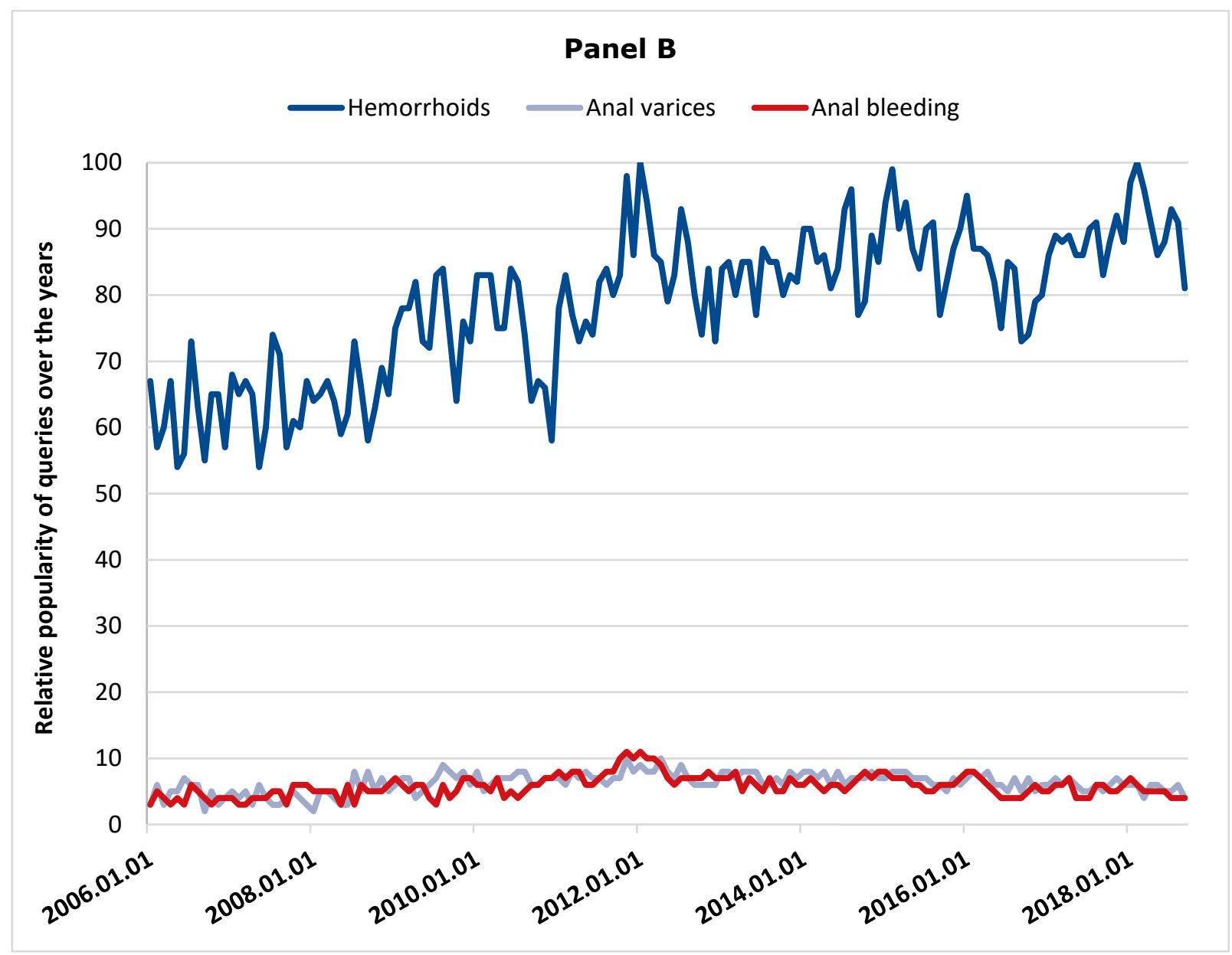


Table 2. Complete results of the internet reliability analysis

\begin{tabular}{|c|c|c|c|c|c|}
\hline Lp & $\begin{array}{l}\text { Links in order } \\
\text { of search results }\end{array}$ & Category & Authorship & Organic/Ad & $\begin{array}{c}\text { Type } \\
\text { of website }\end{array}$ \\
\hline 1 & $\begin{array}{l}\text { http://jmalys.pl/ } \\
\text { hemoroidy.html }\end{array}$ & Professional & MD & ad & outpatient clinic \\
\hline 2 & http://www.criorectum.pl & $\begin{array}{l}\text { Non- } \\
\text { professional }\end{array}$ & lack of data & ad & drug company \\
\hline 3 & http://procto-hemolan.pl & $\begin{array}{c}\text { Non- } \\
\text { professional }\end{array}$ & lack of data & ad & drug company \\
\hline 4 & http://www.fine6.pl & $\begin{array}{c}\text { Non- } \\
\text { professional }\end{array}$ & lack of data & ad & drug company \\
\hline 5 & $\begin{array}{c}\text { http://www.poradnik } \\
\text { zdrowie.pl }\end{array}$ & Professional & MD & organic & health website \\
\hline 6 & $\begin{array}{c}\text { http://www.poradnik } \\
\text { zdrowie.pl }\end{array}$ & Professional & MD & organic & health website \\
\hline 7 & http://www.medonet.pl & $\begin{array}{c}\text { Non- } \\
\text { professional }\end{array}$ & lack of data & organic & health website \\
\hline 8 & http://wylecz.to & Professional & MD & organic & health website \\
\hline 9 & http://proctohemolan.pl & $\begin{array}{c}\text { Non- } \\
\text { professional }\end{array}$ & lack of data & organic & drug company \\
\hline 10 & https://pl.wikipedia.org & Professional & $\begin{array}{c}\text { based } \\
\text { on literature }\end{array}$ & organic & encyclopedia \\
\hline 11 & http://www.criorectum.pl & $\begin{array}{c}\text { Non- } \\
\text { professional }\end{array}$ & lack of data & organic & drug company \\
\hline 12 & https://portal.abczdrowie.pl & Professional & $\begin{array}{c}\text { based } \\
\text { on literature }\end{array}$ & organic & health website \\
\hline 13 & http://gastrologia.mp.pl & Professional & MD & organic & health website \\
\hline 14 & http://lubikowski.pl & Professional & MD & organic & health website \\
\hline
\end{tabular}

Medical professionals often have to struggle against their patients' misinformation. While it is a common belief that information that can be found on the Web is of low quality, our research shows that it is not necessarily true. Majority of the analyzed websites are authored by MDs or are based on medical literature, and are easy to understand. That may explain why as many as $63 \%$ of patients that researched hemorrhoids were satisfied with the information they obtained. On the other hand, quality of the information on the Web concerning different colon diseases is not always satifactory. Yeung et al showed that out of 200 websites about surgery for diverticular disease only 60 (30\%) provided patient-oriented information. Despite the fact that, symptoms, complications, investigations and treatment options were thoroughly described, only $22(36.7 \%)$ of the websites were found as information relevant [15]. In addition, analyzing 100 
sites about surgical treatment for Crohn's disease only half of them provided details on treatment options and only one was recognized as informative [16].

Our study has some potential limitations. We observed a much higher percentage of women in our patient group what is not explained by published epidemiology of hemorrhoidal disease this however may be a random occurrence [17]. Moreover, our data may be biased due to the fact that surveys were collected in a specialized surgical outpatient clinic. Localization of our clinic in a large city may have influenced the demographics of our study group. The mechanisms of Google search engine may be another limitation. While organic links are presented in the same order for every user due to SEO (Search Engine Optimization), Ad Words are specific for every internet user's location, search patterns and cached files. That is why every search is unique to the user and cannot be fully reproduced. In addition, we expect that some of our participants may have used advertisement blocking tools which prevent many ads from appearing on their screens, thus making the searches completely different.

\section{Conclusions}

We would like to underline the fact that Internet is a source of medical information which patients prefer and consider as important. Additionally, the knowledge available on the Internet is freely accessible and of good quality. Both doctors and public campaigns should consider patients' preferences in obtaining medical knowledge and point them to quality sources.

\section{Acknowledgements}

The study is no financial support for the described research. The authors do not have any conflicts of interest to declare.

\section{References}

1. Mishali M, Avrech T. [Who affects the patient, dr. Google or thr doctor?]. Harefuah. 2015 Sep;154(9):556-9, 609.

2. Społeczeństwo informacyjne w Polsce w 2015 r. [Polish only] [Internet]. Główny Urząd Starystyczny. 2015 [cited 2019 Apr 15]. Available from: https://stat.gov.pl/files/gfx/portalinformacyiny/pl/defaultaktualnosci/5497/2/5/1/spoleczenstwo informacyine w polsce 2015 - notatka.pdf

3. Społeczeństwo informacyjne w Polsce w 2016 r. [Polish only] [Internet]. Główny Urząd Statystyczny. 2016 [cited 2019 Apr 15]. Available from: https://stat.gov.pl/obszary-tematyczne/nauka-i-technika-spoleczenstwo-informacyine/spoleczenstwo-informacyine/spoleczenstwo-informacyjne-w-polsce-w-2016-roku,2,6.html

4. Madoff RD, Fleshman JW. American gastroenterological association technical review on the diagnosis and treatment of hemorrhoids. Gastroenterology. 2004;126(5):1463-73.

5. Badger SA, Gilliland R, Neilly PJD. The effectiveness of flexible sigmoidoscopy as the primary method for investigating colorectal symptoms in low-risk patients. Surg Endosc. 2005;19(10):1349-52.

6. Nuti SV, Wayda B, Ranasinghe I, Wang SI, Dreyer RP, Chen SI, et al. The Use of Google Trends in Health Care Research: A Systematic Review. Voracek M, editor. PLoS One. 2014 Oct 22;9(10):e109583.

7. McCormack TT, Bailey HR, Simms JM, Johnson AG. Rectal varices are not piles. Br J Surg. 1984;71(2):163.

8. Arya V, Chang T, Dong H. What's trendy? Ask Google. Pharm Today. 2013;19(7):28.

9. Lee J, Ratcliff C, De Vivo M, Clarke A. No. 1 position in Google gets 33\% of search traffic [Study] | Search Engine Watch. 2013.

10. Wyszukiwarki, silniki " gemius Ranking - [Polish only] [Internet]. [cited 2019 Mar 14]. Available from: $\underline{\text { http://ranking.gemius.com/pl/ }}$

11. Wikipedia contributors. Organic linking [Internet]. Wikipedia, The Free Encyclopedia. 2015 [cited 2019 Mar 14]. Available from: https://en.wikipedia.org/wiki/Organic linking

12. What is Google AdWords? | Google AdWords Benefits - Google [Internet]. [cited 2019 Mar 14]. Available from: https:// support.google.com

13. Diaz JA, Griffith RA, Ng JJ, Reinert SE, Friedmann PD, Moulton AW. Patients' use of the Internet for medical information. J Gen Intern Med. 2002;17(3):180-5.

14. Wong DK-K, Cheung M-K. Online Health Information Seeking and eHealth Literacy Among Patients Attending a Primary Care Clinic in Hong Kong: A Cross-Sectional Survey. J Med Internet Res. 2019;21(3):e10831.

15. Yeung TM, Mortensen NJ. Assessment of the Quality of Patient-Orientated Internet Information on Surgery for Diverticular Disease. Dis Colon Rectum. 2012;55(1):85-9.

16. Yeung TM, Sacchi M, Mortensen NJ, Spinelli A. Assessment of the quality of patient-orientated information on surgery for Crohn's disease on the internet. Dis Colon Rectum. 2015;58(9):857-61.

17. Johanson JF, Sonnenberg A. The prevalence of hemorrhoids and chronic constipation. An epidemiologic study. Gastroenterology. 1990;98(2):380-6. 